\title{
10. Foreign and travel journalism on West Papua: The case of the Swedish press
}

\section{ABSTRACT}

This article analyses the characteristics of a considerable part of the foreign and travel journalism on West Papua that was published in the Swedish press during the period 1959-2009. The analysed material comprises press items, articles, and reports on West Papua published in 27 different Swedish newspapers and periodicals. The comprehensive frame identified in the material is West Papua viewed as a primitive country. Four frames, characteristic of this general frame, are found in the foreign and travel journalism: 1. the primitive Others as dangerous and destructive; 2. the primitive Others as victims; 3 . the primitive Others as admirable; and 4. the primitive Others as timeless and unchangeable. In the foreign and news material, a clear èlite and big power perspective is apparent, which has been fundamental for when the conflict in West Papua is brought up on the journalistic agenda, and when it is not. A power fortifying integration between the frame of West Papua as a primitive country, and the élite and big power perspective exist in the material that during the entire time period covered by this investigation, has resulted in the Papuans being made invisible, and/or maintaining the Papuans and the conflict in West Papua as something odd, not holding a high value.

Keywords: agenda-setting, foreign news, framing, journalistic silence, news agencies, Sweden, the primitive Others, travel journalism, West Papua

\section{THOMAS PETERSSON}

Stockholm University

EST PAPUA, the western part of New Guinea and a former Dutch colony, is a politically-contentious area that since the 1960s, after a criticised United Nations-supervised referendum, is part of 
Indonesia. A West Papuan freedom movement has been active since the 1960s, and the Indonesian oppression has caused the death of many Papuans through the years. At the end of the 1990s and in the beginning of the 21 st century the Indonesian regime tried to split West Papua into several provinces (today the area officially consists of two Indonesian provinces). In 2002, West Papua received extended autonomy, but the Papuan opposition against the Indonesian central power has continued. The Indonesian regime has responded to the Papuan resistance with continued violence and assaults on human rights (see for example Asian Human Rights Commission et al., 2013; Braithwaite et al., 2010), and the conflict between the Papuans and the central power in Jakarta has now been going on for half a century.

In May 1963, the Indonesian administration took over West Papua from the temporary UN administration UNTEA (United Nations Temporary Executive Authority). Since then the Indonesian regime has tried to prevent critical journalistic reporting from the area (Robie, 1989). Directly after the Indonesian take-over a presidential decree, aiming to stop all Papuan political activities, was issued. The decree prohibited Papuan political parties and meetings, demonstrations and the publishing of articles that were not approved by Jakarta (Budiardjo \& Liong, 1988, p. 19). West Papua even became a prohibited area to foreign journalists (Saltford, 2003, pp. 74-75), and has been so over decades. The restrictions on journalists have been maintained in varying degrees until today.

After President Suharto's fall in 1998 a more open political climate was perceived. As the Papuan claims for independence grew stronger, restrictions tightened again and also affected foreign journalists. In 2004 a prohibition on foreign journalists visiting West Papua was implemented (International Federation of Journalists, 2006), and today it is impossible to exercise free and independent journalism in the area. In 2010 and 2011, West Papua was by far, according to Pacific Media Centre media freedom report 2011, 'the most serious case of media freedom violations in the Pacific' (Perrottet \& Robie, 2011, p. 153). Papuan journalists are watched over by Indonesian authorities and they are exposed to threats and violence. Without prior control by the Ministry of Information, foreign journalists are not permitted to travel in West Papua, and those who are allowed access after a drawn-out and bureaucratic process to obtain the necessary visa, are always accompanied by a minder from the National Intelligence Body. Only three journalists were allowed 
access to West Papua on journalist visas during the first eight months of 2011 (ibid., p. 178). In December 2012, Indonesia's Foreign Minister claimed in a press report that 35 foreign journalists, most of them travel reporters, had been permitted to visit West Papua during the last year. Seven journalists were, according to the report, denied entry to the area (Roberts, 2012). In a statement in January 2013, it was concluded that the violence against journalists in West Papua, 'remains the most immediate issue in regional affairs' (Pacific Freedom Forum, 2013).

The present study examines how West Papua has been narrated in the Swedish press, and how successful the Indonesian regime has been in its ambitions to gloss over the political situation in West Papua. The study focuses on Swedish foreign and travel journalism, the two dominating forms of journalism about West Papua. The article discusses the characteristics of a considerable part of the foreign and travel journalism on West Papua, published in Swedish press during a period of 50 years. The article is based on 387 press items, articles and reports on West Papua, published in the Swedish press during the period 1959-2009 (cf. Petersson, 2012). The foreign journalism includes 361 news items, articles and reports, while the travel journalism comprises 26 travel reports. Articles from 27 different newspapers (19) and periodicals (8) are included.

The material has been collected from the company Bibliotekstjänst that during the entire period investigated has registered articles from many Swedish newspapers and periodicals. Material has also been collected from the digital archives Pressarkivet and Mediearkivet. In addition, complementary research has been carried out at the Swedish National Library's newspaper microfilm archive, as well as at two of the major newspapers' (Dagens Nyheter and Expressen) clipping archives. An overall principle in the selection of the foreign journalism that is included in the analyses, is that all the material has been published in the Swedish daily press and mainly deals with the political situation in West Papua. All such material found is part of the analysis. The analysed foreign material has mainly been published in the daily newspapers' foreign pages, and consists in a great part of news material from the Swedish news agency TT and the international news agencies. When it comes to travel journalism, the analysed material also includes periodicals. The travel journalism consists of cultural descriptive reports with connections to amusement reading and the growing tourist industry. In all the analysed travel reports 
the writer has been on the ground in West Papua, and the material is often published in special travel pages.

The collected material was analysed by means of a qualitative framing analysis, applying a cultural theoretical perspective. Focus has been on how the material relates to comprehensive cultural conceptions (cf. Reese, 2010). One entry into the material was how foreign and travel journalism relate to cannibalism, but other notions have been allowed to appear during the analysis process, to illuminate important impact-holding features. During the analytic procedure, close readings of the material were carried out on repeated occasions, and the different types of material were compared during the whole process. During the analysis, the position of the material in the newspaper, headlines, photos, ingresses, phrases, key notions, selection of sources, stereotypes, layout, and graphic signals, were noted.

It was also deemed important to investigate the historic legacy that the material is a part of, as well as studying the links to frames of the primitive Others in areas other than journalism, in order to elucidate how the frames are organised and structured in a more fundamental manner. As a consequence, the study also includes a considerable amount of written secondary material. This material consists of travel narratives in book form, Swedish Foreign Office documents, and material produced by the tourism industry. Without the secondary material, the investigated foreign and travel journalism would appear more culturally freestanding than is actually the case.

Two instances of fieldwork in West Papua in the 2000s improved the prospects of placing the travel journalism into a relevant context. A vital part of the fieldwork was to study social interactions in the tourism environment, where a considerable part of travel journalism on West Papua has been constructed, by means of participatory observations. The fieldwork yielded contextual knowledge, later of importance to the understanding of the analysis of separate travel reports. To further enable the placing of the journalistic material into a relevant context, questions were also put to journalists who had been working in West Papua, and the author of this article also used his own experiences of working as a journalist in the area.

\section{The primitive Others}

According to anthropologist William Arens' book The Man-Eating Myth (1979), Africa represented the most important contrast to the Western civilisation during the 1800 s, while in the 1900 s this role was assumed by New 
Guinea (p. 193). According to Rupert Stasch (2011a), another anthropologist, the figure of the primitive in West Papua is maintained (in travel writing) in a form of a 'hall of mirrors', where different components, moving about in an iconic network, mutually support each other. 'Everywhere a reader turns, the different elements mirror and confirm each other, and mirror and confirm an overall mythic idea of dramatic encounter between civilised white people and primitive black people' (p. 11). In this study, the 'cannibal' is conceived as a symbol of the most primitive, having held significance in different political, economic, and historic contexts, not least during colonialism of $1800 \mathrm{~s}$ and 1900s.

The study adopts a cultural theoretical perspective, in line with the accepted approach within media research, where journalistic texts are viewed as being constructed within different social contexts, while simultaneously having an impact on social contexts. The study draws on framing theory, and on previous research, showing that journalism and media assume the perspectives of the power élite. One starting point is that journalism is affected by comprehensive cultural imaginations, comprising more than the news assessments, conventions and economic preconditions, that are specific to journalism and media. The journalism professor Stephen D. Reese (2001, 2010) is an important source of inspiration. Reese defines frames as 'organising principles that are socially shared and persistent over time, that work symbolically to meaningfully structure the social world' (2001, p. 11, 2010, p. 17). According to Reese (2010), frames are always an abstraction; they manifest themselves in various directions, and he argues that the frames tend to be more general and extensive than the journalism's own production of news themes, factual issues and topics (p. 18, 21).

Another starting point in the study is that frames exert some form of power. The power does not necessarily constitute the visible and prominent. Frames may also support certain interests, even though no conscious underlying intentions and strategies exist. The most effective power may rather be the one that prohibits conflicts to emerge at all (Reese, 2001, p. 16-17). Since frames are connected with cultural arrangements, using them appears so normal and natural that their social construction remains invisible, or is at least hard to notice. For this reason, because the frames often being implicit and unnoticed, they often make an impression on an unconscious level (cf. Van Gorp, 2007, p. 63-64). 
To categorise foreign people, "the "Others", is in this study conceived as something constant in the history of mankind. A starting point is that the conceptions of the Papuans/the primitive Others are flexible, but that does not exclude later structures and figures of thought. Human action and cultural concepts do not arise from a vacuum, and the actors always seem to be influenced and formed to some extent by previous structures.

\section{Swedish journalists on the ground in West Papua}

At the end of the 1940s and during the 1950s, the Swedish author Sten Bergman carried out three journeys to the then-Dutch New Guinea (1948-49, 1952-53 and 1956-58). The year-long expeditions resulted in three widelyread travel books. Bergman also lectured and contributed to newspapers, radio and television and during the 1950s was one of the most prominent authors in Sweden. Through later decades he has influenced Swedish New Guinea travelers, not least by his most well-known book My father is a cannibal (1959). Bergman's prominent position and his great influence may be the reason for West Papua being more narrated in Sweden than in many other countries.

In 1976, a series of articles on West Papua was published by Monica Braw (and the photographer Juhani Lompolo) in the Swedish newspaper Kvällsposten. Monica Braw was, as far as is known, the first Swedish journalist to visit West Papua after the Indonesian takeover in 1963. Also seen from an international perspective, Braw's reported journey must have been an early exception. On the ground in West Papua, Braw (and Lompolo) did not meet or hear about any other journalists that had been there. The area was prohibited to investigative journalists. Braw's series of reports is, though, an example of the Indonesian regime permitting a restricted form of journalistic activity in the middle of the 1970s. More than 30 years after the reported journey, Braw answers the question about why she and Lompolo gained access:

We certainly got our visas since we again and again claimed that we were solely [my italics] going to write about how we followed the footsteps of Sten Bergman. We [Braw and Lompolo] were of course conscious of the independence movement, but since it was a big project to reach Sten Bergman's villages, we concentrated on that. (Braw, 2008) 
Through the publishing of Monica Braw's reports in Kvällsposten in May and June, 1976, a form of narrative emerged again that, like those by Sten Bergman, did not attach importance to the political situation in West Papua. Instead, the primitive Others were in focus and the editorial fascination was great. Of the six reports, three were on the newspaper poster all of them promising a journey to the Stone Age. The reports are based on Monica Braw following Sten Bergman's footsteps to the area around the missionary station Karubaga, close to the Baliem Valley in the Papuan highlands. In contrast to Sten Bergman's report from the area, ${ }^{1}$ narratives about cannibalism take an important part in Braw's reports, and the visited area is in the reports called the Cannibal Valley.

At the same time as Monica Braw was let into West Papua the Indonesian regime was to open up the area for limited tourism. During the so-called New Order and Suharto's period as a President (1967-98), the tourism industry was a means to spread an image internationally of Indonesia as a politically-stable nation. Already in 1969, an official political programme was drawn up to invest in tourism as a means of getting income from foreign visitors, as a strategy to create national unity among the many ethnic groups, and as a way to obtain a good reputation internationally. The Indonesian regime has acted in a rational and calculated way towards the development of the tourism industry, that has been centrally-governed and well-planned (Dahles, 2001).

In 1976, a group of tourists led by the Swede Magnus Andersson, arrived in West Papua. Magnus Andersson became, through the arrangement of this group travel to the Baliem Valley and Asmat, an international precursor in the tourism industry in West Papua. Throughout decades tourists from Europe and North America have been able to participate in Magnus Andersson Expeditions' travels to West Papua, following the footsteps of Sten Bergman, as a result of the Swedish travel organiser's good relations with Indonesian authorities. In the 1980s several reports about West Papua were published in the Swedish press by journalists/tourists who had participated in Magnus Andersson's group travels.

In the 1990s Indonesian authorities opened up to a greater extent for individual tourism in West Papua, where the Baliem Valley was the main tourist attraction, which could be noticed in Swedish travel journalism. During the 1990s at least 10 reports about West Papua were published in the Swedish press by Swedish journalists who travelled in the Baliem Valley. Some of the 
reports were published in the most widely-circulated newspapers in Sweden. During the period 1999-2009, no travel reports about the Baliem Valley are to be found in the Swedish press. The obvious political and social changes that the Baliem Valley went through towards the end of the 20th century could no longer satisfy Western desire for the untouched and the unspoiled, which left the closely-connected tourism industry and travel journalism (cf. Fürsich \& Kavoori, 2001) try to find new areas to explore.

During later years, the ideas about and the desire for the primitive Others have been nourished by Korowai and Kombai people, who traditionally build their houses high up on the tree-trunks or in the crowns. Magnus Andersson arranged his first group journey to the Korowai and Kombai area in 1994, and until 2007 he carried through about 20 journeys with Western groups. Several reports about the Korowai and Kombai were published in some of Sweden's most circulated periodicals. Even internationally the media interest has been huge. Reports about the Korowai and Kombai people have been published in international newspapers and periodicals, some of them with millions of readers (cf. Stasch, 2009, p. 1, 2011a, p. 2). Several films have circulated internationally through television companies and channels like BBC, France 2 and Discovery Channel (Stasch, 2011b, p. 75). Only a few thousand tourists have so far visited the 'treehouse people' but hundreds of them have been professional film-makers and journalists (Stasch, 2011a, p. 2), and the Korowai and Kombai people have in the 21 st century been one of the most narrated people on New Guinea.

Meanwhile although the travel pages in Swedish newspapers and periodicals have not lacked material about West Papua/the primitive Others, but they have been immensely quiet about the political conflict on the foreign news pages. The only Swedish journalist in West Papua after the Indonesian takeover in 1963 who got his material published on the foreign news' pages in one of the major Swedish daily newspapers, is the author of the present study.

During nearly two months at the end of 1996 and at the beginning of 1997, I travelled around West Papua on a tourist visa (with Sten Bergman's book My father is a cannibal in my luggage), in order to, as a freelance journalist, gather politically-oriented material for journalistic articles and a book. ${ }^{2}$ The journalistic material was later published in Dagens Nyheter, the morning newspaper with the largest circulation in Sweden (similar versions were also published in newspapers in the other Nordic countries). 
When the report was sold to the foreign editorial office of Dagens Nyheter, I was present when the choice of photographs was made hastily at the newspaper's entrance at the head office in Stockholm. Dagens Nyheter chose a picture of a man in a penis gourd (there were alternatives without primitive attributes available). The decision was made in the twinkling of an eye, but it was not by mere chance. The choice was commented on by the foreign editor of the paper who said that if something was to be published about New Guinea, that kind of photograph was the most suitable for the article.

The headline of the article was formulated as follows: ' 30 years of struggle for freedom: Stone Age guerilla fights for independence from Indonesia' (Petersson, 1997). The headline in combination with the preamble (which I wrote myself), and the photograph of a nameless man in a penis gourd, is packed with ideas of the Stone Age and the primitive that could hardly have been constructed in other contexts. I was part of the procedure. I was permeated with stereotypes and evolutionary ideas and by combining politics with penis gourds and the primitive, I assumed the commercial possibilities of getting published would increase. During a few moments at the entrance of Dagens Nyheter - without any of us being especially aware of this - a cultural heritage and ideas about the primitive Others, with its origins a long time before Sten Bergman, were accentuated. At the same time as stereotypes were developing, the same stereotypes implied that the political conflict in West Papua for a short moment was brought onto the journalistic agenda in one of the most established Swedish newspapers.

\section{Agenda-setting and framing interacting}

The comprehensive frame identified in the Swedish press material is West Papua as a primitive country. During the process of analysis, four frames, characteristic of this general frame, were identified. The frames are all founded on the same organising principle, i.e. the conceptions of West Papua being a primitive country, but are more or less dominant/frequent in the different types of analysed material. The following four frames were recognised:

1. The primitive Others as dangerous and destructive: Built on the preconception that the Papuans are uncivilised in comparison with the civilised West, with the 'cannibal' as the prime symbol of the uncivilised. The frame describes the Papuans as a threat and a problem. This type of frame has a long history, with a deeply-cultural 
anchorage, and is in the material found in a manifesting as well as a more latent form.

2. The primitive Others as victims: Built on the notion that the Papuans' political rights/will are in principle unreachable and/or unrealistic. The Papuans are portrayed as victims rather than actors with possibilities of influencing the development in a political process. This frame is closely linked with frame number 1 above. A manifestation of this linkage may be that cannibalism and other imaginations of the primitive Others more or less explicitly are linked with the conflict. Another expression of the victim frame may be that the Papuans' political vulnerability is noted, but not taken as seriously as in other conflicts.

3. The primitive Others as admirable: Built on the idea that the Papuans have a lifestyle, or possess characteristics, that (at least on a shallow level) are regarded as worth striving for/desirable, since they have something that is lost in the West. An example of this type of frame is the romanticising picture of the Others' way of living close to nature, which has long been found in travel narratives. It may also involve an admiration of more social characteristics. The quest for the genuine and native is closely coupled to this frame.

4. The primitive Others as timeless and unchangeable: Built on the conception/wish that the Papuans will/should remain what they always were, that is to say primitive. An example of this type of frame is when the Papuans are delineated as unaffected by time and space. This frame type is closely linked with the primitive Others as admirable. A clear visual symbol of the primitive Others as timeless and unchangeable, is the penis gourd.

The first frame above (1) may be linked to foreign as well as travel journalism; the following (2) primarily to foreign journalism, and the last two ( 3 and 4) first and foremost to travel journalism. The identified frames should not be acknowledged as static or unchangeable, where each separate article or press item may be placed in accordance with an exact schedule. The different frames might actually rather permeate each other, and several of them might appear in one and the same article.

A prominent abstraction in the material, besides cannibalism, is the Stone Age. Stone Age may be loaded with negative assessments of something 
dangerous and destructive as well as with positive assessments of something genuine and native; and the concept may in principle be included as an element in all the frames identified above. A visual symbol, frequently recurring in the material, and closely coupled to the abstractions of and the fixations at Stone Age, are the penis gourds.

An approach towards the Papuans that may result in all the identified frames above, is the primitive Others as something exciting and appealing. Several examples in the material illustrate how interest in New Guinea and the Papuans by individual journalists may contribute to putting West Papua (and the conflict) onto the journalistic agenda. This approach towards the Papuans, this agenda factor, is built on the idea that the primitive Others represent something fascinating - in a negative sense (the 'cannibal'), but also in a positive sense (natural and unspoilt). At the same time, a considerable streak of degrading judgments has throughout the years led to a journalistic neglect and invisibility of the Papuans. Making the Papuans invisible has, along with the conflict, obvious connections to the factors more directly related to journalism.

A definite élite and big power perspective crystallises in the foreign and news material, which has been fundamental for when the conflict in West Papua is put onto the journalistic agenda, and when it is not. Within journalism, the élite and big power perspective can mainly be coupled to six fundamental factors that influence what is reported and what is not reported, i.e. what is constructed as a news item and becomes part of the journalistic agenda, and what will not become a news item. The élite and big power perspective comprises the following six issues/factors in the material:

1. The international news agencies' concentration in the world's political and economic power centres, and their adaptation to the markets within these centres of power.

2. The news agencies' dependency on political measures taken by the élite sources within the big powers that have been involved in the conflict in West Papua.

3. Expressions of violence, and threats of violence transpiring, as an important news criterion when élite persons/big powers are, or risk becoming, involved in the conflict.

4. Newspapers' dependency on the international news agencies putting the conflict onto the agenda. 
5. Newspapers'/collaborators' dependency on élite sources and their tendency to be part of the èlite and big power perspective themselves.

6. Newspapers'/collaborators' adaptation to the market, and/or their inability to independently assess and put an un-established conflict onto the agenda.

These underlying factors manifest themselves in the foreign and news material by an overwhelming emphasis in the news agency material on various political measures taken by élite persons who have wished to make comments in order to preserve their own political and economic interests in West Papua (points 1 and 2). The élite and big power perspective is emerging throughout the entire period investigated, but the reporting on the conflict diverges, chiefly depending on whether the élite sources had an interest in making comments or if they did not. The news reporting was most extensive during two periods in the 1960s, when the big powers had a peak interest in making comments.

During the 1960s, the conflict in West Papua was on the agenda on some occasions. Élite sources within the big powers that were most involved in the conflict (Indonesia, Holland, the US and the UN) gave their opinions and the international news agencies reported, especially in connection with violence or menace of violence at the beginning of the 1960s. When the big powers risked becoming violently involved in the conflict there were reports, otherwise not. When the international news agencies reported, the conflict was also highlighted by Swedish newspapers. At the end of 1961 and in the beginning of 1962 - the most news-intensive period of this study - the conflict was on the agenda on the foreign news pages and editorials of the most important daily newspapers, as well as in the local press. During this period the conflict in West Papua also came up on the front pages of the major newspapers, which hasn't been repeated in later times.

A structural journalistic silence was also appearing in the foreign and news material, also built on the élite and big power perspective. During the 1970s and 1980s, only two news items from the Swedish news agency TT and the international news agencies on the conflict are found in the material, in spite of the repression of the Papuans being extensive at that time. The existence of journalistic actors, who during the 1970s and 1980s contributed to breaking the journalistic silence on the conflict, is utterly limited or non-existent. 
The secondary material of this study (see above) discloses that the frame of West Papua as a primitive country is part of a historic legacy. The secondary material also shows that the colonisation of West Papua to a considerable extent has been influenced by a culture where degrading attitudes towards the Papuans have been internationally spread - and established at the highest political level, not least during the 1960s, and the UN-supervised referendum in 1969 (see Saltford, 2003; Drooglever, 2010). The prevailing political and economic order, along with the discrimination against the Papuans, have been maintained more or less consciously by a number of actors: from the United Nations, independent states, companies, international news agencies, the Swedish news agency TT, and other media enterprises, to individual collaborators within these organisations. Cultural notions and frames, within journalism and elsewhere, have contributed to sustaining the political and economic order; and the case of West Papua provides support to Stuart Hall (1997a) and his research that unveils that culture not only is a part of society, but is constitutive of the societal order, as important to consider as the economic and material 'base' (pp. 5-6).

This study shows that the well-established Swedish foreign journalism on West Papua has been part of an élite and big power perspective, and supports that with extensive research concluding that news values mostly are built on èlite sources and élite perspectives (see for example Galtung \& Holmboe Ruge, 1965; Gans, 1979; Tuchman, 1978; Wu, 2000, for a Papuan example, see Matbob \& Papoutsaki, 2006). Furthermore, there is in the material a power-strengthening integration between the élite and big power perspective, and the frame of West Papua as a primitive country, which during the whole time period investigated has resulted in making the Papuans invisible, and/or sustaining the Papuans and the conflict in West Papua as something peculiar, not of equal value. As long as the political pursuit of the Papuans has been depicted as a primitive curiosity, it has been easier to obtain a place in the media spotlight, but without primitive straitjackets it has been difficult or impossible for Papuans to make their political voices heard. Actors within Swedish journalism who have tried freeing themselves from abstractions of the primitive Others, have experienced difficulties in reaching the established media. Instead, the Swedish editors and writers, in conjunction with public expectations, commercial demands, the Indonesian regime, and other political and economic power centres, have rather observed a 'cannibal', or a 'Stone 
Age man wearing a penis gourd', than a politically-conscious Papuan, reporting on the multinational companies' exploitation of the natural resources.

Since the 1960s several big powers have had immense political and economic interests in West Papua. Even a, so to say, periphery country like Sweden has participated in the exploitation of West Papua's natural assets. The Swedish company Sandvik has 350 employees within the huge American mining company Freeport-McMoRan's Grasberg mine in West Papua (the world's biggest gold-mine), and the Swedish pension funds (the AP-funds) have invested money in the criticised American mining company. Sweden's Foreign Minister Carl Bildt was a former shareholder and member of the board of Lundin Petroleum, a Swedish oil company with interests in West Papua.

The prohibition by Indonesian authorities of investigative journalism on West Papua, as well as the well-established Swedish newspapers' élite and big power perspective and the expected framing of West Papua as a primitive country, has prevented important and pertinent journalism being published. Since the end of the 1980s a number of relatively young and un-established Swedish freelance journalists have proposed investigations on the conflict in West Papua after visiting the area on tourist visas (with all the following restrictions). This material has had difficulties reaching the more well-established newspapers. Among Swedish freelance journalists there has been an ambition to place Papuans side-by-side, and try to get rid of the 'hall of mirrors' (see above), which probably has rendered the possibilities to get published by the well-established press difficult.

The unresponsive attitude towards freelance material about West Papua is also connected to the élite and big power perspective. By taking an affirmative publishing decision about an unknown conflict area, the élite and big power perspective upon which the well-established press is built, is challenged in its principles (cf. points 4-6 above). The longer a conflict has been going on and the less it has been reported, the more challenging it is and the higher are the needs for capacity to discharge journalistic self-criticism. Another difficulty for freelance journalists is that the well-established press prefers its own reporters, and not unknown freelance journalists proposing material about a conflict unknown to many editors (cf. Davies, 2012, p. 75).

\section{Conclusion}

West Papua, within established Swedish journalism, still remains an almost impregnable antipole to the civilised West. When New Guinea is brought up 
for discussion, cognitive schemas with a long past are activated, and ideas about West Papua as a primitive country continue to be shared by those who have been there and by those who are reduced to the narratives of the media. There may be ways out from the 'hall of mirrors' of the primitive Others and openings to more equal approaches, but the impact they have had in the case of Swedish journalism is exceedingly small. It is therefore most probable that many people in Sweden (and internationally) continue to live with the ideas that Papuans in fact are too primitive to become independent. More probable though is that the élite and big power perspective of the news and foreign journalism, and the structural journalistic silence, have implied that there is no reason to reflect on the question of Papuan independence.

No journalists in the material have succeeded in freeing themselves from the élite and big power perspective and the frame of West Papua as a primitive country. From the journalists and other actors in the material, operating in West Papua, it is evident that an extended presence in the country and meetings with the Others might be an asset if dominating preconceptions are to be challenged and changed. It is however paradoxical that several journalists as well as other actors, having had a more or less longstanding relationship with West Papua, originally founded their 'political engagement', or a more equal approach to the Papuans, on a fascination with the native and primitive (not least the author of this study). This relationship underlines the impact of culture when it is acting on an unconscious level, permeating large parts of the society (cf. Van Gorp, 2007, p. 63-64). The power is not necessarily repressive (cf. Hall, 1997b, pp. 49), and in the case of West Papua, some of those who have been striving to achieve equality for the Papuans, and perhaps change the existing political and economic order, have through their own conceptions participated in sustaining the very issues they wish to counteract. Hence, the Indonesian regime along with other actors do not mind the existing order being maintained, having in their severest enemies also their best friends. The Western fascination and desire for the primitive Others have concealed the political reality, and the existing political and journalistic order has, unfortunately for the Papuans, been like a self-playing piano in duty of the Indonesian regime. 


\section{Notes}

1. Sten Bergman clearly expressed his opinion about cannibalism in the New Guinea highlands: 'The mountain people of New Guinea are neither head-hunters nor cannibals' (Bergman, 1959, p. 126).

2. Braw and Lompolo are the only journalists known in the present study who got visas to carry out journalistic activities in West Papua. Other journalists have, as far as is known, travelled on tourist visas. After my report journey was finished, I applied for a visa at the Indonesian embassy in Stockholm, saying that I wanted to go there as a journalist and write about the political situation. The application was a test of Indonesian openness. Despite repeated promptings the application was never answered.

\section{References}

Arens, W. (1979). The man-eating myth: Anthropology \& anthropophagy. Oxford: Oxford University Press.

Asian Human Rights Commission (2013, March 12). Indonesia: Ongoing violence in Papua and the need for dialogue. Retrieved on March 17, 2013, from http:// www.humanrights.asia/news/alrc-news/human-rights-council/hrc22/ALRCCOS-22-13-2013

Bergman, S. (1959). Min far är kannibal. Stockholm: Albert Bonniers förlag.

Braithwaite, John et al. (2010). Anomie and violence: Non-truth and reconciliation in Indonesian peacebuilding. Canberra: ANU E Press.

Braw, M. (2008). E-mail from Braw to the author, December 11.

Budiardjo, C. \& Liong, L. S. (1988): West Papua: The obliteration of a people. London: Tapol.

Dahles, H. (2001). Tourism, heritage and national culture in Java: Dilemmas of a local community. Richmond, Surrey: Curzon Press.

Davies, K. (2012). Safety vs credibility: West Papua media and the challenge of protecting sources in dangerous places. Pacific Journalism Review, 18(1), 69-82.

Drooglever, P. (2010). An act of free choice: Decolonisation and the right to selfdetermination in West Papua. London: Oneworld Publications.

Fürsich, E. \& Kavoori, A. (2001). Mapping a critical framework for the study of travel journalism. International Journal of Cultural Studies, 4(2), 149-171.

Galtung, J. \& Holmboe Ruge, M. (1965). The structure of foreign news. Journal of Peace Research. 2(1), 65-91.

Gans, Herbert J. (1979). Deciding what's news: A study of CBS Evening News, NBC Nightly News, Newsweek, and Time. New York: Pantheon Books.

Hall, S. (1997a). Introduction.In S. Hall, (Ed.), Representation: Cultural representations and signifying practices (pp. 1-12). London: Sage.

Hall, S. (1997b). The work of representation. In S. Hall (Ed.), Representation: Cultural representations and signifying practices (pp. 13-74). London: Sage.

International Federation of Journalists. (2006, February 17). IFJ says foreign media 
ban in West Papua continues to obstruct press freedom. Retrieved on January 14, 2013, from www.ifj.org/en/articles/ifj-says-foreign-media-ban-in-west-papuacontinues-to-obstruct-press-freedom-

Matbob, P. \& Papoutsaki, E. (2006). West Papuan 'independence' and the Papua New Guinea press. Pacific Journalism Review, 12(2), 87-105.

Pacific Freedom Forum, (2013, January 13). Indonesia brutality towards West Papua 'medieval' - PFF. Retrieved on January 15, 2013, from www.pacificfreedomforum. org/2013/01/indonesia-brutality-towards-west-papua.html

Perrottet, A., \& Robie, D. (2011). Pacific media freedom 2011: A status report. Pacific Journalism Review, 17(2), 148-186.

Petersson, T. (1997, August 11). 30 års kamp för frihet: 'Stenåldersgerilla' strider för självständighet från Indonesien. Dagens Nyheter, p. A11.

Petersson, T. (2012). Landet bortom horisonten: En analys av journalistik om Västpapua i svensk press 1959-2009. [The country beyond the horizon: An analysis of journalism on West Papua in Swedish press, 1959-2009, Ph.D. diss.] Stockholm: Stockholm University.

Reese, S. D. (2001). Framing public life: A bridging model for media research. In S. D. Reese, O. H. Gandy, \& A. E. Grant (Eds), Framing public life: Perspectives on media and our understanding of the social world (pp. 7-31). Mahwah, NJ: Erlbaum.

Reese, S. D. (2010). Finding frames in a web of culture: The case of the war on terror. In P. D'Angelo \& J. A. Kuypers, (Eds.), Doing news framing analysis: Empirical and theoretical perspectives (pp. 17-42). New York, London: Routledge.

Roberts, G. (2012, December 10). Indonesia denies restricting media access to Papua. ABC News Online. Retrieved on January 14, 2013, from www.abc.net.au/ news/2012-12-10/indonesia-denies-closing-papua-to-journalists/4419748

Robie, D. (1989). Och världen blundar ... kampen för frihet i Stilla havet [And the world closed its eyes: Campaign for a free South Pacific]. [Swedish trans. Margareta Eklöf]. Höganäs, Sweden: Wiken.

Saltford (2003). The United Nations and the Indonesian takeover of West Papua, 1962-1969: The anatomy of betrayal. London: RoutledgeCurzon.

Stasch, R. (2009). Society of others: Kinship and mourning in a West Papuan place. Berkeley: University of California Press.

Stasch, R. (2011a). Textual iconity and the primitivist cosmos: Chronotopes of desire in travel writing about Korowai of West Papua. Journal of Linguistic Anthropology, 21(1), 1-21.

Stasch, R. (2011b). The camera and the house: The semiotics of New Guinea 'Treehouses' in global visual culture. Comparative Studies in Society and History, 53(1), 75-112.

Tuchman, G. (1978). Making news: A study in the construction of reality. New York: The Free Press.

Van Gorp, B. (2007). The constructionist approach to framing: Bringing culture back in. Journal of Communication, 57(1), 60-78.

Wu, D. (2000). Systemic determinants of international news coverage. A comparison of 38 countries. Journal of Communication, 50(2), 110-130. 
Dr Thomas Petersson is a Swedish journalist. He visited West Papua for the first time in 1987 and has since then carried out four report journeys to the area as a freelance journalist. His work has resulted in two books (in Swedish) about the political situation as well as articles that have been published in the Swedish and international press. This article is based on his 2012 doctoral thesis at Stockholm University, Landet bortom horisonten: En analys av journalistik om Västpapua i svensk press 1959-2009 (The country beyond the horizon: An analysis of journalism on West Papua in the Swedish press, 1959-2009). batte52@hotmail.com

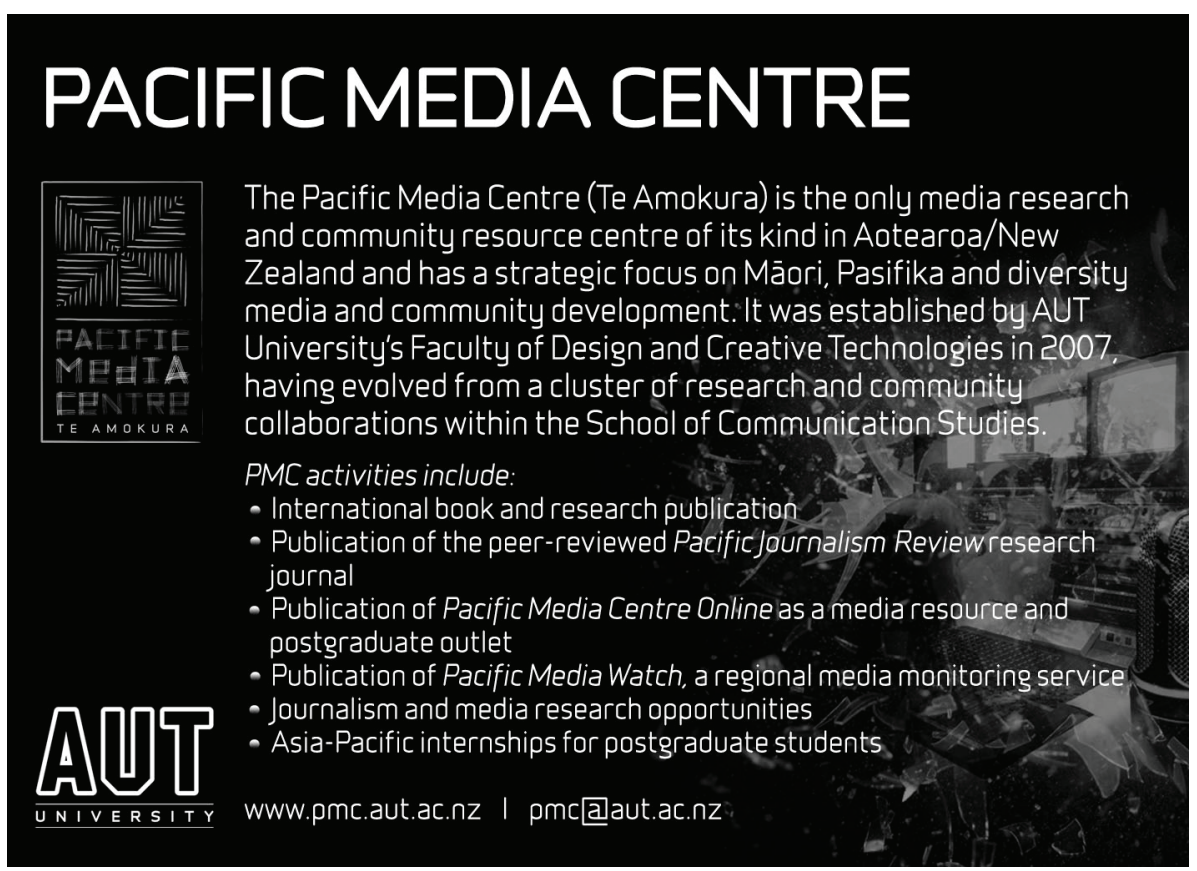

